\title{
Lead-dependent infective endocarditis with a giant vegetation in the heart around an externalised VDD pacing lead. VDD lead externalisation in the course of tribological lead wear
}

\author{
Odelektrodowe infekcyjne zapalenie wsierdzia z olbrzymią wegetacją w sercu \\ wokół rozszczelnionej elektrody VDD — eksternalizacja przewodów w przebiegu \\ trybologicznego zużycia elektrody
}

\section{Krzysztof Boczar ${ }^{1}$, Barbara Małecka ${ }^{1,2}$, Andrzej Ząbek ${ }^{1}$, Zbigniew Samitowski ${ }^{3}$, Jacek Lelakowski ${ }^{1,2}$}

'Department of Electrocardiology, John Paul II Hospital, Krakow, Poland

${ }^{2}$ Institute of Cardiology, Jagiellonian University Medical College, Krakow, Poland

${ }^{3}$ Department of Cardiac Surgery, John Paul II Hospital, Krakow, Poland

A 48-year-old patient, after implantation of a VDD pacemaker 10 years ago and after pacemaker replacement 6 months ago, was repeatedly hospitalised for the last 4 months for recurrent upper respiratory infections and exercise tolerance deterioration with a decrease in body weight of $10 \mathrm{~kg}$ and increased inflammatory parameters: C-reactive protein $70.82 \mathrm{mg} / \mathrm{L}$ $(<5 \mathrm{mg} / \mathrm{L})$, white blood cells $21.87 \times 10^{3}(1 / \mu \mathrm{L})$, D-dimer $6461 \mu \mathrm{g} / \mathrm{L}(<500 \mu \mathrm{g} / \mathrm{L})$. The patient was diagnosed with bronchitis and sinusitis. Other complaints were explained as neurosis. Correct diagnosis was made after angio-computed tomography examination - where septic pulmonary embolism of the arteries of the lower lobes was revealed. These were followed by transthoracic and transoesophageal echocardiography, which confirmed the presence of vegetation associated with the endocardial lead. In multiple positive blood cultures growth of Staphylococcus capitis was found, and targeted antibiotic therapy was implemented. On the basis of the modified Duke criteria for endocarditis, a diagnosis of lead-dependent infective endocarditis was made, and the patient was qualified for pacemaker system removal. In chest $\mathrm{X}$-ray an excess of VDD lead in the right heart cavities was shown and the externalisation of wires in the distal portion of the lead was suspected. Due to the large size of the vegetation (the length: $71 \mathrm{~mm}$ ) connected to the lead and its coarse

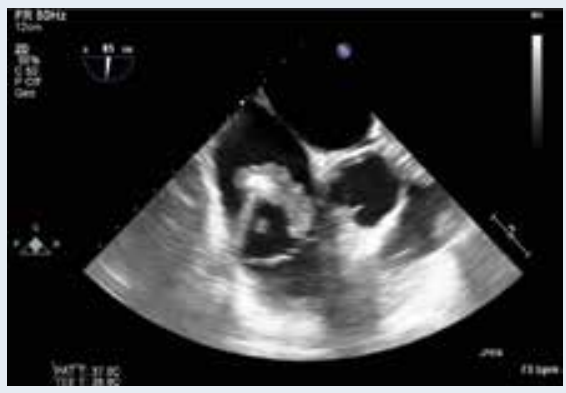

Figure 1. Transoesophageal echocardiography examination - vegetation on the lead in the right atrium and the right ventricle with length approximately $71 \mathrm{~mm}$

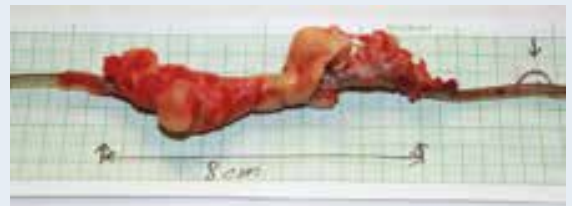

Figure 2. View of the operating field — VDD pacing lead with visible vegetation (arrows)

texture (Fig. 1), the patient was qualified for complete system removal during cardiac surgery with cardiopulmonary bypass. During the procedure, the lead was removed completely with the total mass of the vegetation (Figs. 2, 3). Also, externalisation of two internal cables was confirmed (Fig. 4). Further course of hospitalisation was uneventful. Reimplantation of the pacemaker was postponed. In conclusion, the presented VDD lead externalisation has not been described so far in literature. Due to the different structure of VDD leads, in relation to the classical pacing leads and the defibrillation leads, there were no analyses on this subject in the literature dealing with the phenomenon of wire externalisation.

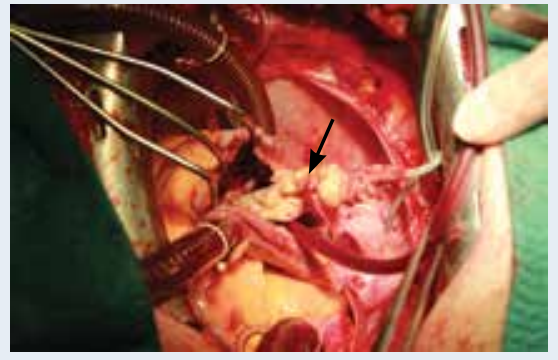

Figure 3. Removed lead fragment with vegetation approximately $8 \mathrm{~cm}$ in length. The arrow indicates the location of lead wire externalisation

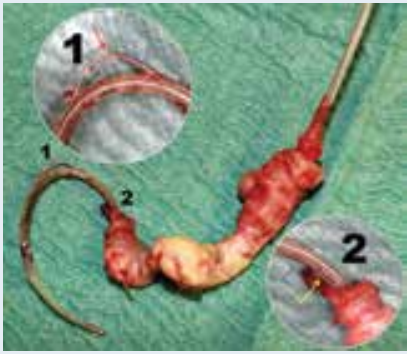

Figure 4. Magnification of lead wire externalisation in frames $(1,2)$

Address for correspondence:

Krzysztof Boczar, Department of Electrocardiology, John Paul II Hospital, ul. Prądnicka 80, 31-202 Kraków, Poland, e-mail: krzysiek.boczar@gmail.com

Conflict of interest: none declared 